\title{
Cultural Criticism of Post-modernism Cultural Marxism
}

\author{
Chuan Wang \\ Ideological and Political Department \\ Yunnan College of Business Management \\ Kunming, China
}

\begin{abstract}
Post-modernism cultural Marxism, a Western Marxist trend of thought that has emerged and had extensive influence under the new historical conditions where significant change has taken place in contemporary capitalism, has quickly become a critical cultural trend that questions the mainstream values of Western modern society. It deconstructs traditional philosophy in a radical way. The cultural questioning of the rational foundation of capitalism and the promotion of its differential philosophy to contemporary multiculturalism is close to the revolutionary critical spirit of Marxism in theoretical nature. The achievements of cultural critical theory of post-modernism cultural Marxist are mainly manifested in the inheritance of the critical spirit of Marxism, the excellent phenomenological and pathological analysis of the new development of contemporary capitalism, and the richness of Marxist innovation space in the West. Its defects are manifested in the internal conflict of theoretical content, the deviation of theoretical essence from historical materialism, and anarchism in politics.
\end{abstract}

Keywords—cultural Marxism; cultural criticism; Marxism

\section{INTRODUCTION}

Cultural criticism has always been the traditional theme of Western Marxism. Post-modernism cultural Marxism is the initiator of the transition of Western post-modern culture, which raises the cultural criticism of Western New Marxism to capitalist consumer society to a new historical height. Although the cultural critical theory can be divided into several levels, there is no unified theoretical form, but there are roughly basic themes and formal logic. Its cultural critique of the bourgeois consumer society is gradually promoted with the new development of capitalism. It goes deep into the root-seeking cultural genetic criticism of postmodernism from the alienation criticism of human nature to criticism of experience and common sense of society.

\section{THE ACHIEVEMENTS OF THE CRITICAL THEORY OF POST-MODERNISM CULTURAL MARXISM}

\section{A. Inheriting the Critical Spirit of Marxism}

Recognizing the criticalness of theory and method is the main feature shared by post-modernism cultural Marxism and Marxist theory. The combination of postmodernism and Marxism mainly devoted to the differentiation of Marxism.
Postmodern Marxism has not formed a unified philosophy. They seek "differences" and the pursuit of difference is their common context and goal. In this vision, Marxism is not so much a legacy as a spirit. "We can't do without Marx; since there is no Marx, there is no memory of Marx or Marx's legacy, and there is no future... at least there should be some kind of spirit of him." ${ }^{1}$ It can be seen that the postmodernism cultural Marxism recognizes and emphasizes the critical spirit of Marxism. In terms of spiritual temperament, it reflects the relationship with traditional Marxism, namely a thorough criticism of tradition and reality. In this sense, postmodernism cultural Marxism expands the Marxist domain of discourse in the new context of post-modern knowledge.

Based on the radical critical spirit and the interpretation of the relationship between knowledge and power, the postmodernism cultural Marxism has re-evaluated and positioned the critical role of culture in the post-modern society, deepening the cultural critique of the traditional Western New Marxism. Postmodernism is born out of structuralism (ie., deconstruction). Some post-modernism cultural Marxists also try to use Marxist dialectics to analyze postmodernism, explain and criticize the cultural ideology of capitalism, but they finally returned to the critical spirit of Marxism in the process of analyzing and deconstructing capitalism. Since then, the criticism of the post-modernism cultural Marxism to traditional mode of thinking has been more extensive and intense than the previous poststructuralism and it has developed postmodernist theoretical discourse with the core of in the fields of politics, society, history and culture to criticize modernity and made unique interpretation of Marxism from a special perspective, which opens up a discourse analysis model that is both related to but totally different from Marxist ideology research, but also draws on the essence of Marxist cultural theory and breaks through the traditional Western social theory and rationalist philosophical framework, raising the criticism of the capitalist consumer society to a new height.

Therefore, the so-called post-modernism cultural Marxism is more in line with Marxism in terms of spiritual temperament and ideological connotation. It is precisely the critical spirit of Marxist theory that provides a possibility for

Derrida: "The Ghost of Marx - Debt Country, Mourning Activities and New International", China People's Publishing House, 1999, p. 21. 
some kind of connection between postmodernism and Marxism. Although this radical cultural criticism of postmodern Marxism is different from the proletarian liberation cause advocated by Marxism and does not have universality and inevitability, its two advantages of clinging critical spirit and practical character are obviously from Marxism. The new role of post-modern Marxism on contemporary intellectuals highlights the radical practice criticism of intellectuals in the post-modern knowledge state, which is the embodiment and continuation of the critical spirit of Marxism under contemporary historical conditions. At the end of the 20th century, the right trend of western deMarxism was in the mainstream of the western ideological circle. The post-modern Marxism uplifted the critical spirit of Marxism, and even the cultural struggle it represented is ultra-left, scattered, and marginal, its spirit is also meaningful and valuable.

\section{B. Providing Excellent Phenomenological and Pathological Analysis of the New Development of Contemporary Capitalism}

Post-modernism cultural Marxism provides an excellent phenomenological and pathological analysis of the contemporary bourgeois consumer society with various forms of theoretical analysis in the historical conditions of the new development of capitalism. The expansive development of the contemporary bourgeois consumer society is a phenomenon that didn't appear in the 19th century when Marx lived. The post-modern Marxism cultural criticism emerged at the right moment when the traditional theory is unable to provide ready-made explanations and answers to this new social state, which is a theoretical reflection of this profound change in contemporary capitalist society. It uses Marxism and various new social theoretical resources to expose and criticize the contemporary bourgeois consumer society. For example, Baudrillard's Simulacrum, and "implosion" theory reflect the re-construction of people's cognitive style under the conditions of great changes in contemporary social politics, economy and culture. Combining with the new characteristics of capitalism, it focuses on the combination of culture and economic politics in the development of contemporary capitalism, and theorizes the central role played by culture in the reproduction of contemporary capitalist society. This theory has made Marxist criticism to the legitimacy of consumer capitalist society and its dominant ideology, which is a new expression of the new stage of capitalism made by contemporary neo-Marxism.

The cultural criticism made by post-modernism cultural Marxism to capitalist consumer society is panoramic, allround, and quite deep; it is also a cultural criticism theory of capitalist consumer that positively applies Marxist theory to contemporary reality with originality and postmodern orientation. It follows the general principle of critical Marxism, expands Marx's value theory and commodity fetishism theory from the new dimension of cultural symbolic value, reveals the social construction process of subject dominated by object in the state of materialization of consumer society, analyzes the formation of social control in contemporary capitalism and exposes the cultural logic of late capitalism, which provides useful contemporary critical materials and analytical perspectives for classical Marxism.

With the deepening and expansion of the globalization process, some developing countries in the process of modernization have also seen the characteristics of consumer society within local scope, so the post-modernism cultural Marxism has practical significance. However, it should be pointed out that the reference of developing countries to the critical theory of Western culture Marxism cannot only be discourse translation that is directly applied to the reality of these countries. Compared with western developed countries in the post-modernization state, China's social productivity level, production mode, social relationship structure, and national cultural tradition have direct characteristics and uniqueness. At this stage, consumption has not benefited the most extensive social class. Therefore, the cultural significance of consumption cannot be the same as that of Western society. Thus, we must develop the cultural criticism of Marxism in the unique context of Chinese society and scientifically grasp the degree of analysis and criticism.

\section{Enriching the Innovative Space for Marxism in the West}

Postmodernism Marxism expands the new vision of capitalist criticism with a broad cultural perspective, enriches the Marxist cultural critique, and thus releases and provides a Marxist innovation space and platform in the contemporary West. The most characteristic of post-modernist culture Marxism is its openness and inclusiveness. On the one hand, it has infiltrated radical criticism into various academic fields and popular culture fields, and has carried out microscopic but pervasive criticism of contemporary capitalist society. Its critical tentacles extend from the phenomenological aspect of the consumer society to the most secret cultural genetic level formed by the control mechanism of capitalist power. The post-modern Marxist cultural critique is not limited to the field of literature and art, which is not a narrow cultural critique, but a generalized critique of capitalism. It represents a great cultural view similar to the Marxist cultural criticism, and it is also the inheritance of the thorough critical spirit of Marxism. On the other hand, the post-modernism Marxist cultural criticism has developed a pluralistic cultural critical theory, which is extremely inclusive and open. It has melted all kinds of theoretical resources into a single furnace, taking in everything, and tried to constantly innovate theory and transform society. The high speed at which post-modernism cultural Marxism denies its own thoughts and frequent promotion of the innovation and advancement of its theory are the typical manifestation of the theoretical inclusiveness of post-modernism cultural Marxism. Similarly, the view of post-modernism cultural Marxism on innovating Marxism is also rich in thought. Based on the faithful realistic thinking on changes of the times and the challenges faced by Marxism in the contemporary Western knowledge context, it believes that in face of political and economic systems, "oldfashioned Marxist cultural paradigms have been difficult to use." Post-modernism cultural Marxism proposes open and pluralistic Marxist political and cultural discourses, 
integrates the various criticizing positions of contemporary Europe and the United States into comprehensive dialectical theory, and critically absorbs the rational thought of various non-Marxist discourses or system. Interpretive models or systems such as psychoanalysis, mythological criticism, text criticism, ethical criticism, and structuralist criticism are all incorporated into their postmodern-oriented Marxism. To demonstrate the inclusiveness of Marxist critique to other modes of interpretation is to achieve the historicization of various critical methods through "signal-code conversion" and to incorporate them into the critical framework of Marxism. Therefore, the post-modernist cultural Marxism has a distinct political and cultural critical spirit, and it shows an innovative and comprehensive theoretical attitude. Although the innovation of Marxism made by this theory is not universally accepted and recognized and the new Marxist theories have different judgment on it, after all, it has formed a new wave of capitalist cultural criticism.

\section{THE DEFECTS OF CUlTURAL CRITICAL THEORY OF POST-MODERNISM CULTURAL MARXISM}

\section{A. There Is an Inherent Conflict in the Content of Theory}

In post-modern cultural Marxism, there is always a debate about whether post-modernism and Marxism can be combined. Generally speaking, the connection between the two in methodology is accepted. That is to say, postmodernism absorbs the critical method of Marxism, but it is generally considered that there is an internal conflict between the theoretical contents of the two. It is precisely because of the diversity and inclusiveness of post-modernism cultural Marxism that it brings the integration of a great deal of viewpoints to its theory. However, the integration of a large number of viewpoints does not mean that they are necessarily compatible. The theoretical views of multiple perspectives appear simultaneously in the post-modernism cultural Marxism, which inevitably become a potential danger that in many cases these postmodern views are not all harmoniously compatible with Marxism, and some postmodern viewpoint are simply not compatible with Marxism. Therefore, in this alternative vision, the theoretical content of Marxism and postmodernism is indeed contradictory in many cases. Fundamentally speaking, Marxism is a macroscopic historical theory, and postmodernism requires the resolution of all rationality and the deconstruction of all the grand narratives of totality. The two theories themselves inevitably have internal conflicts. At the same time, post-modernism cultural Marxism mainly analyzes the cultural nature and contradiction of capital, but neglects the logic of capital itself as well as the basic position of labor and production in contemporary social structure. There is obviously a significant distance between it and political economy and historical materialism of Marxism.

Marx pointed out: "Philosophers only explain the world in different ways but the problem is to change the world. 2 "The difference between interpretation and change is

Selected Works of Marx and Engels, Vol. 1, People's Publishing House, 1995, p. 57. whether theory and practice is separated or combined. In Marx's view, history is not created by heroes as rational tools, but by the people's social practice activities; the rationality of theory can only be tested in the course of practical activities, which is not just a philosophical deduction. Marx emphasized: "All social life is essentially practical. Any mysterious thing that leads theory to mysticism can be reasonably resolved in human practice and the understanding of this practice." According to Marx's theory, the radical cultural criticism of post-modernism cultural Marxism is still a way of interpreting the world rather than changing the world, which still belongs to the "mysterious thing that leads the theory to mysticism." Once this micro-style cultural criticism encounters the harsh macro-political and economic reality of capitalist society, it immediately shows its inability and insignificance. In the post-modernism cultural Marxism, the conflict between the micro-critical orientation of postmodernism and its philosophical uncertainty and the fundamental purpose of transforming and overthrowing capitalism and the certain logic of Marxist is almost inevitable.

\section{B. The Theoretical Essence Deviates from Historical Materialism}

In post-modernism cultural Marxism, it mainly reflects the transformation of post-modernism to Marxism, rather than the opposite. Therefore, it is not willing to involve the affirmative content of Marxism, but reinterprets Marxism with pluralism and nihilism that is against rational rule. Postmodernism cultural Marxism is radical in superficial form, but in essence it is non-Marxist and is a denial of the principle of historical materialism.

The struggle of post-modern oriented Marxism is completely different from the liberation of rationality and freedom pursued by Marxist historical materialism based on historical necessity. The emergence of post-modern knowledge state makes the grand narrative of modernity present a legitimacy crisis, and the small narrative based on difference and heterogeneity becomes the basis of postmodern knowledge state. It is consistent with the spirit of postmodernism's deconstruction of "meta-narrative". Therefore, post-modern Marxism deconstructs and splits the view that Marxist regards the general approach to the regularity and inevitability of historical development as "grand narrative" with a radically critical position, trying to replace Marxism with pluralistic micro-politics.

According to the principle of historical materialism, the development of society is a natural historical process, and shows a "combination force" in the mutual conflict of various forces, which highlights the general inevitable trend of historical development, namely regularity. The development of capitalism also belongs to the natural historical process, and it has the inevitable law of its emergence, development and demise. Post-modernism cultural Marxism replaces identity with pluralism, replaces economic and political analysis with cultural criticism, and opposes capitalist macro politics with micropolitical criticism. Fundamentally, it denies that social development is a natural history, does not recognize any objective necessity 
of the development of social history, and denies the basic principles of historical materialism. In this sense, the pluralist micro-political criticism of post-modernist cultural Marxist does not touch the essence of capitalism, so it is impossible for it to reveal the historical destiny of capitalism inevitably going to its demise. Its critical strength is very limited.

\section{Politically Leading to Anarchism}

Post-modernism cultural Marxism critique disintegrates materialism monism with pluralism ideologically and politically advocates micro-political criticism based on multiple differences, thus forming the main theoretical basis of the anarchist tendency in Western left-wing politics. It should be noted that in contemporary Western society, the social pluralism advocated by post-modernism cultural Marxism has certain positive significance for criticizing the reality of capitalism, and to a certain extent promotes the development of contemporary Western democracy. Postmodernism cultural Marxism criticism attempts to use social pluralism as a weapon to mobilize various social forces scattered on the edge of capitalist society to form a multifaceted cultural attack on capitalism and transform capitalism. The micro-political criticism that post-modernism cultural Marxism is enthusiastic about and engaged in is not improper, but the problem lies in that it end up with the micro-political criticism with post-modern orientation, instead of extending its cultural criticism to a broader macroscopic field. It not only lacks the macroscopic historical vision of Marxism, but is also not interested in the capitalist economic and political criticism, and it is based on deconstructing and rejecting the "grand narrative" of Marxism. Thus, the micro-politics criticism of postmodernist cultural Marxist is completely divorced from the practice of socialist movement under the guidance of Marxism. It is outside the practice of macroeconomics and politics socialist movement that socialist forces use to oppose capitalist system and the macroeconomic and political criticism and social fighting that socialist forces use to oppose the capitalist system. Therefore, it has become a trivial, subtle and irrelevant criticism without resistance spearhead. Therefore, the radical cultural resistance of the social pluralism of post-modernism cultural Marxism is only a personal, niche, and anarchist struggle. It does not interfere with the inherent logic of the wealth accumulation of capitalism, nor does it form a fundamental blow to the political system of capital exploitation. The post-modernism cultural Marxism intends to form a shock from the edge of the scattered capitalist society to the center through radicalization and ultra-left of Marxism, but this effort is counterproductive, which is not only conducive to restoring the status and reputation of Marxism in the West, but its natural tendency of anarchism may lead to the compromise and recognition of the fundamental system of capitalism, thereby weakening and damaging the struggle of the socialist left wing against capitalism. Finally, the new rise of postmodernism Marxism criticism has not really played a strong restricting or contending role to it.

\section{CONCLUSION}

Post-modernism cultural Marxism, the initiator the transition of post-modern culture in the West, provided theory and methodology for various new Marxist schools since the 1970s. It deconstructs traditional philosophy in a radical way and has a fierce critical attitude towards the existing social order. The cultural questioning of postmodernist Wenhu Marxism towards the rational foundation of capitalism and the promotion of contemporary multiculturalism by its differential philosophy is close to the revolutionary critical spirit of Marxism in the theoretical temperament. However, the post-modernism cultural Marxism denies all "grand narratives" and deconstructs the Marxist general approach to the regularity and inevitability of historical development, thus deviating from the basic principles of historical materialism. It replaced the class rule of Marxist with modern micro politics. This form of pluralistic autonomous struggle at the micro level is a kind of powerless fight against capitalism and does not truly reflect the critical spirit of Marxism.

\section{REFERENCES}

[1] Selected Works of Marx and Engels, Vol. 1, People's Publishing House, 1995

[2] Derrida. "A Crazy Guardian - Interview with Derrida", Shangha People's Publishing House, 1997.

[3] Eribon. Power and Rebellion, Peking University Press, 1997.

[4] Liu Beicheng. Portrait of Foucault's Thought, Beijing Normal University Press, 1995. 